\title{
Studi Mekanisme Kegagalan Las pada Riser Wall Tube Nomor 2 ASTM A210 Grade A- 1 pada Pembangkit Listrik Tenaga Uap Unit 2 PT X
}

\author{
Fajar Adi Prasetya, Lukman Noerochim, dan Rochman Rochiem \\ Jurusan Teknik Material dan Metalurgi, Fakultas Teknologi Industri, Institut Teknologi Sepuluh \\ Nopember (ITS) \\ Jl. Arief Rahman Hakim, Surabaya 60111 Indonesia \\ e-mail:lukman@mat-eng.its.ac.id
}

\begin{abstract}
Abstrak-Riser wall tube merupakan salah satu bagian yang sangat penting pada boiler di PLTU PT X dimana fungsinya adalah menyalurkan uap dari furnace menuju steamdrum. Kasus yang didapatkan pada boiler ini adalah bocornya riser wall tube nomor dua pada saat proses sedang berjalan. Untuk mengetahui penyebab bocornya tube tersebut dan mencegah terjadinya kasus yang sama, maka analisa kegagalan terhadap riser wall tube tersebut perlu dilakukan. Pada penelitian ini dibuat spesimen pembanding sebagai acuan. Beberapa pengujian seperti pengujian liquid dye penetrant, pengujian tarik dilakukan pada spesimen las pembanding serta pengujian metalografi dan pengujian kekerasan dilakukan pada kedua spesimen juga dengan tambahan pengujian spektrometri, pengujian SEM dan pengujian XRD untuk spesimen yang mengalami kegagalan. Spesimen las pembanding dibuat sesuai dengan WPS yang ada. Dari hasil pengujian yang telah dilakukan terdapat perbedaan pada daerah las di kedua spesimen. Keduanya memiliki struktur mikro dan nilai kekerasan yang berbeda. Pengujian SEM pada spesimen las yang mengalami kegagalan menunjukkan adanya porositas dan hasil pengujian XRD-nya menunjukkan adanya senyawa korosi. Porositas, korosi, serta hasil las yang tidak memenuhi standar menyebabkan kualitas las menjadi tidak maksimal.
\end{abstract}

Kata Kunci-boiler, riser wall tube, las, bocor

\section{PENDAHULUAN}

$\mathrm{P}$ EMBANGKIT Listrik Tenaga Uap atau yang biasa disingkat sebagai PLTU merupakan sebuah pembangkit yang menghasilkan energi listrik dari hasil konversi energi kinetik uap. Generator uap, atau boiler, menggunakan panas untuk mengubah air menjadi uap untuk berbagai aplikasi. Yang paling utama adalah pembangkitan tenaga listrik dan proses pemanasan pada dunia industry. Uap merupakan sumber daya utama karena ketersediaannya yang luas, sifatnya yang menguntungkan dan tidak beracun. Pengkonversian energi tersebut dilakukan oleh generator yang dihubungkan pada satu poros dalam turbin. Turbin dapat berputar karena mendapat gaya kinetik dari uap panas yang dihasilkan oleh boiler. Sehingga dapat disimpulkan ada tiga komponen utama pada sebuah PLTU, yaitu boiler, turbin, dan generator. Sebagai salah satu komponen utama pada PLTU, tentunya boiler mempunyai peranan yang sangat penting. Fungsi utama pada boiler adalah sebagai tungku pemanas untuk memanaskan air sehingga menjadi uap panas yang selanjutnya akan dimanfaatkan untuk memutar turbin [1]. Layaknya peralatan lainnya, boiler juga dapat mengalami kegagalan. Apabila mengalami kerusakan pada salah satu bagian pada boiler maka efisiensi kerja pada boiler menjadi berkurang sehingga dapat mengakibatkan kerugian finansial yang tidak sedikit. Selain itu, apabila salah satu bagian pada boiler mengalami kerusakan dapat menyebabkan terganggunya proses pada PLTU untuk melakukan perbaikan sehingga PLTU tidak dapat memenuhi permintaan daya yang dibutuhkan untuk menyuplai listrik karena harus di shutdown.

Salah satu bagian pada boiler yang tak luput dari kerusakan adalah riser wall tube. Riser wall tube berfungsi untuk menyalurkan campuran air dan uap yang dihasilkan di ruang bakar utama menuju steamdrum [2]. Pada kasus ini, ditemukan gagalnya riser wall tube di salah satu unit boiler milik PT X.

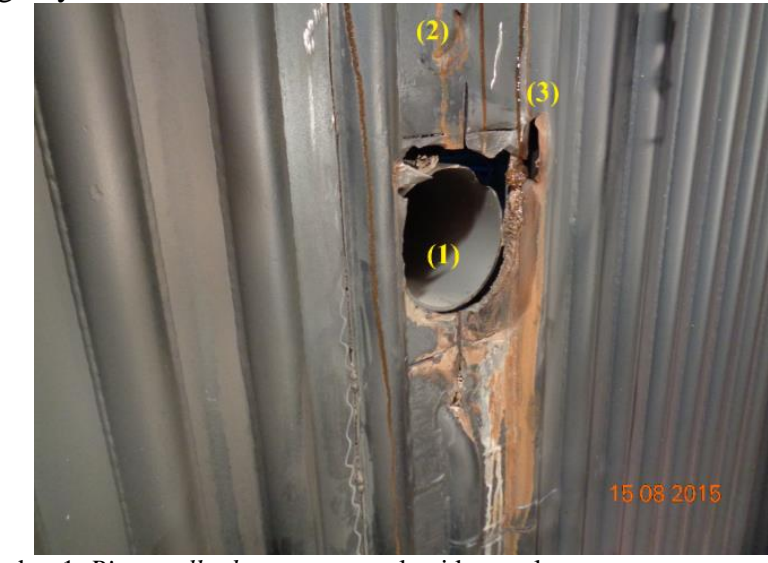

Gambar 1. Riser wall tube yang mengalami kegagalan

Tube nomor 2 (gambar nomor 2) dan tube nomor 3 (gambar nomor 3) yang terletak di dekat sootblower (gambar nomor 1) terlihat mengalami kebocoran. Namun penyebab serta mekanisme kegagalan pada kedua tube tersebut berbeda. Banyak faktor yang dapat menyebabkan gagalnya kedua tube tersebut. Faktor penyebab kegagalan yang sering terjadi di dunia industri diakibatkan oleh beberapa faktor, yaitu kesalahan dalam pemilihan material, perawatan komponen yang kurang baik, kesalahan dalam perancangan komponen, dan kondisi lingkungan yang ekstrem [3]. Oleh karena itu, diperlukan suatu analisa secara menyeluruh untuk mengetahui secara pasti faktor - faktor penyebab dari gagalnya riser wall tube tersebut, khususnya nomor 2. Analisa yang dilakukan berupa analisis dari segi metalurgi sehingga dengan dilakukannya kegiatan 
analisa ini dapat diketahui penyebab dan mekanisme dari gagalnya boiler tersebut serta dapat dijadikan sebagai dasar acuan untuk mencegah terjadinya kegagalan yang sama di kemudian hari.

\section{METODOLOGI PENELITIAN}

\section{A. Diagram Alir Penelitian}

Berikut merupakan diagram alir yang dilakukan pada penelitian ini:

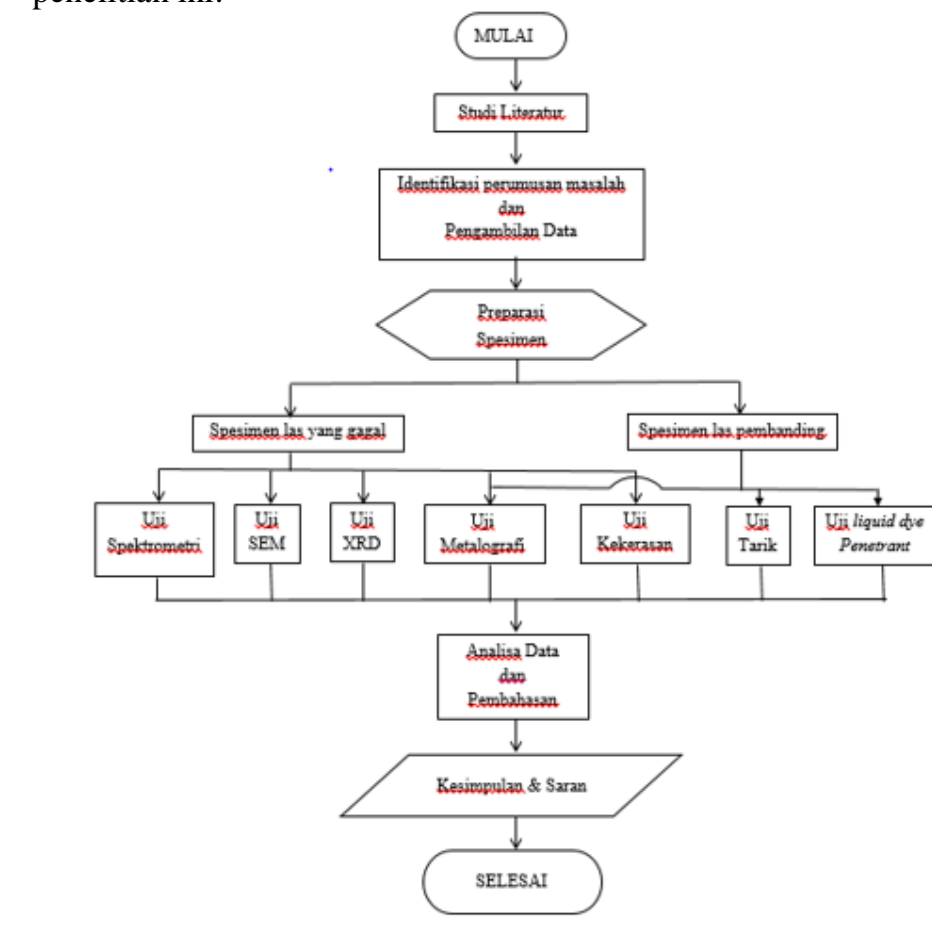

Gambar 2. Diagarm alir penelitian

\section{B. Peralatan yang digunakan}

Peralatan yang digunakan pada penelitian ini antara lain, jangka sorong, mesin potong, mesin grinding, alat kikir, mesin polish, kamera digital, mikroskop optic, mesin las SMAW, mesin uji kekerasan, mesin uji tarik, mesin uji spektrometri, mesin uji SEM, dan mesin uji XRD.

\section{Bahan yang digunakan}

Bahan yang digunakan pada penelitian ini antara lain, baja ASTM A210 grade A-1 [4], elektroda AWS E7016 [5], kertas gosok grade 80 sampai 2000, larutan Nital , penetrant, cleaner/remover, developer.

\section{Preparasi Spesimen}

Material yang digunakan pada penelitian ini adalah baja ASTM A210 Grade A-1 dan elektroda AWS E7016. Spesimen yang digunakan ada dua buah yaitu spesimen las yang mengalami kegagalan dan spesimen las pembanding. Spesimen las pembanding dibuat sesuai dengan WPS yang sama pada riser wall tube dan juga dengan menggunakan base metal dan elektroda yang sama, yaitu baja ASTM A210 grade A-1 dan elektroda AWS E7016.

\section{E. Pengujian Komposisi}

Pengujian spektrometri adalah pengujian yang bertujuan untuk mengetahui komposisi kimia yang terdapat pada spesimen las yang mengalami kegagalan. Pada identifikasi komposisi kimia menggunakan alat Spectra Analyze Foundry Master.

\section{F. Pengujian Liquid Dye Penetrant}

Pengujian penetrant dilakukan pada daerah las spesimen pembanding yang telah dibuat. Pengujian ini dilakukan dengan tujuan untuk mendeteksi adanya kerusakan atau diskontinuitas pada permukaan pada hasil las. Pengujian penetrant dilakukan dengan menggunakan penetrant SKL-SP2 dan developer SKDS2

\section{G. Pengujian Tarik}

Pengujian tarik dilakukan pada spesimen las pembanding yang telah dibuat dan dilakukan pengujian penetrant. Pengujian ini dilakukan dengan tujuan untuk memastikan apakah las yang dibentuk sudah dilakukan dengan baik atau tidak. Spesimen dibuat sesusai dengan ukuran standar ASTM E8 [6]. Pengujian tarik dilakukan dengan menggunakan universal tensile testing machine.

\section{H. Pengujian Metalografi}

Pengujian metalografi dilakukan untuk mengetahui struktur mikro spesimen las yang mengalami kegagalan dan spesimen las pembanding yang dilakukan dengan menggunakan alat bantu mikroskop optik. Pengujian struktur mikro ini disesuaikan dengan standar ASTM E3 [7]. Pengamatan metalografi dilakukan dengan menggunakan mikroskop optik Olympus BX51M-RF

\section{Pengujian Kekerasan}

Pengujian kekerasan dilakukan untuk mengetahui nilai kekerasan. Pengujian ini dilakukan baik pada spesimen las yang gagal maupun pada spesimen las pembanding yang selanjutnya akan dibandingkan hasil yang didapatkan pada kedua spesimen tersebut. Pada kedua spesimen, dilakukan indentasi di tiga daerah yang berbeda yaitu base metal, heat affected zone dan weld metal. Pengujian ini dilakukan dengan metode Vickers sesuai dengan standar ASTM E92 [8]. yang menggunakan indentor berupa piramida intan dengan pembebanan sebesar 30 $\mathrm{kg}$ dengan waktu indentasi selama 10 detik. Pengujian ini dilakukan dengan menggunakan Universal Hardness Tester HBRV 187.5A.

\section{J. Pengujian SEM}

Pengamatan dengan menggunakan mesin scanning electron microscope (SEM) bertujuan untuk menganalisa adanya porositas pada spesimen las yang mengalami kegagalan. Pengujian ini dilakukan dengan menggunakan alat Venom Pro$\mathrm{X}$.

\section{K. Pengujian $X R D$}

Pengujian XRD dilakukan untuk mengamati adanya senyawa korosi pada spesimen las yang mengalami kegagalan. 
Pengujian ini dilakukan dengan menggunakan alat PAN Analytical.

\section{HASIL DAN PEMBAHASAN}

\section{A. Hasil Pengujian Komposisi}

Pengujian komposisi dilakukan pada spesimen las yang mengalami kegagalan. Pengujian ini bertujuan untuk mengetahui kesesuaian komposisi elektroda pada spesimen tersebut dengan komposisi elektroda AWS E7016. Pengujian komposisi menunjukkan hasil yang sesuai dengan komposisi AWS E7016

Tabel 1

\begin{tabular}{ccc}
\hline \multicolumn{3}{c}{ Hasil pengujian komposisi } \\
\hline \hline Unsur & Kandungan $(\%)$ & AWS E7016 \\
$\mathrm{Fe}$ & Balance & Balance \\
$\mathrm{C}$ & 0.11 & $0.12(\max )$ \\
$\mathrm{Mn}$ & 1.58 & $1.60(\max )$ \\
$\mathrm{Si}$ & 0.73 & $0.75(\max )$ \\
$\mathrm{P}$ & 0.04 & $0.04(\max )$ \\
$\mathrm{S}$ & 0.03 & $0.035(\max )$ \\
$\mathrm{Cr}$ & 0.18 & $0.20(\max )$ \\
$\mathrm{Mo}$ & 0.28 & $0.30(\max )$ \\
$\mathrm{V}$ & 0.07 & $0.08(\max )$ \\
$\mathrm{Ni}$ & 0.24 & $0.30(\max )$ \\
\hline \hline
\end{tabular}

\section{B. Hasil Pengujian Liquid Dye Penetrant}

Pengujian liquid dye penetrant dilakukan pada spesimen las pembanding untuk mendeteksi adanya cacat permukaan pada daerah las.

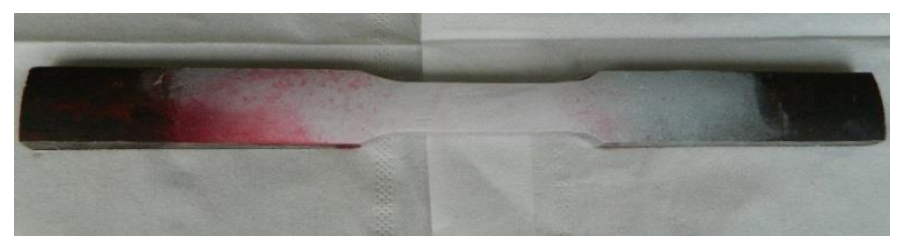

(a)

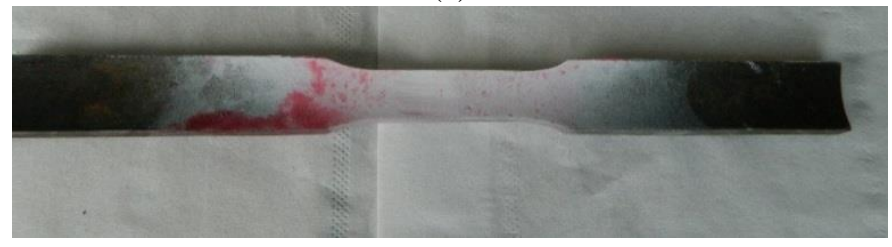

(b)

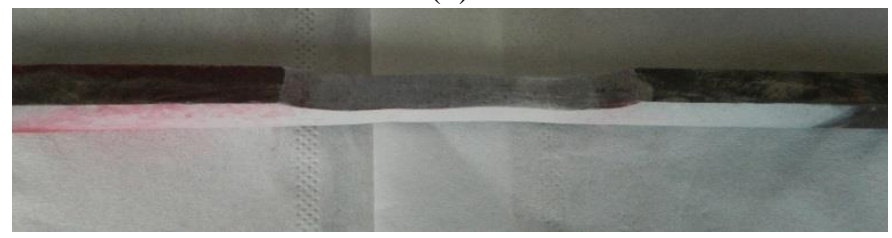

(c)

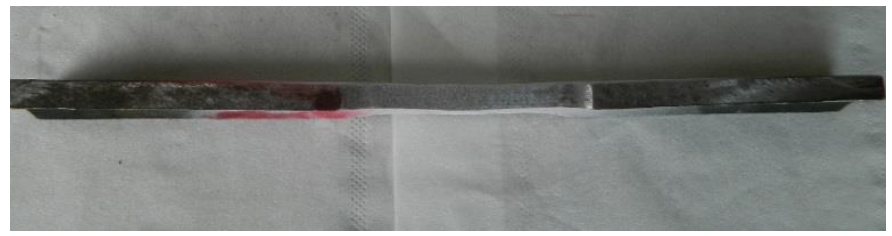

(d)

Gambar 3. Hasil pengujian liquid dye penetrant pada spesimen las pembanding pada: (a) sisi belakang tube, (b) sisi depan tube, (c) sisi kiri spesimen dan (d) sisi kanan spesimen

Sesuai dengan gambar 3 hasil pengujian liquid dye penetrant menunjukkan tidak adanya cacat permukaan pada bagian las dari spesimen las pembanding yang dibuat.

\section{Hasil Pengujian Tarik}

Pengujian tarik dilakukan pada spesimen las pembanding yang dijadikan sebagai acuan.

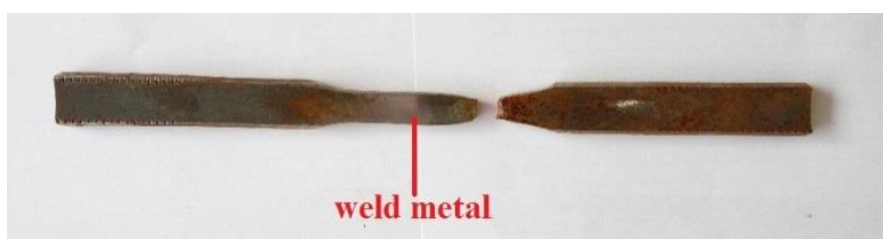

Gambar 4. Hasil Pengujian Tarik

Sesuai dengan gambar 4 hasil pengujian tarik menunjukkan patahan terjadi di daerah base metal sehingga spesimen las pembanding telah dibuat dengan baik dan dapat dijadikan sebagai acuan.

\section{Hasil Pengujian Metalografi}

Pengujian metalografi dilakukan pada spesimen las yang mengalami kegagalan dan spesimen las pembanding. Pengujian metalografi dilakukan untuk mengamati fasa pada kedua spesimen dengan menggunakan alat mikroskop optik. Struktur mikro dapat diketahui dengan cara mengkorosikan batas butir spesimen dengan larutan etsa nital $2 \%$.
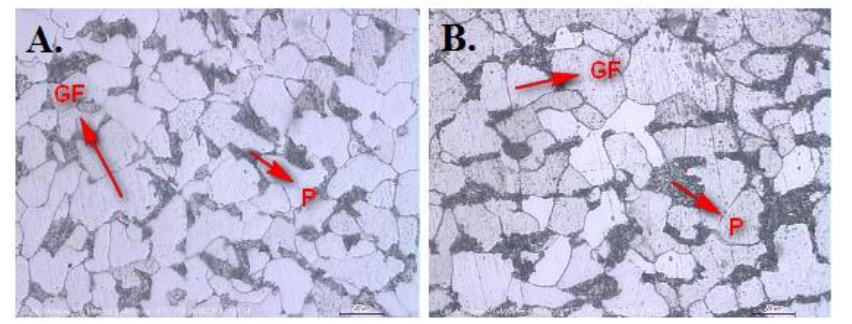

Gambar 5. Hasil pengujian metalografi pada daerah base metal spesimen las yang mengalami kegagalan (A) dan spesimen las pembanding (B) dengan perbesaran 500x

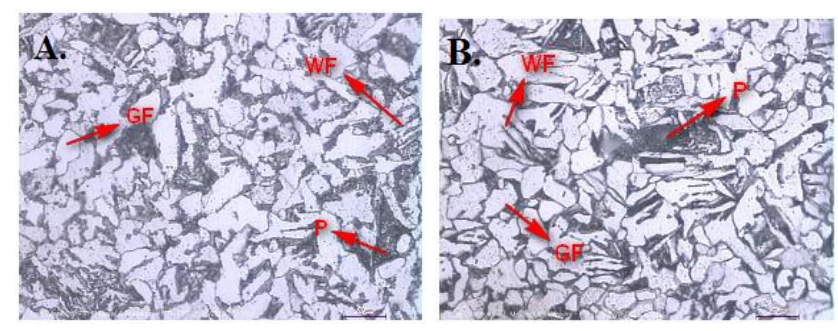


Gambar 6. Hasil pengujian metalografi pada daerah heat affected zone spesimen las yang mengalami kegagalan (A) dan spesimen las pembanding (B) dengan perbesaran $500 \mathrm{x}$

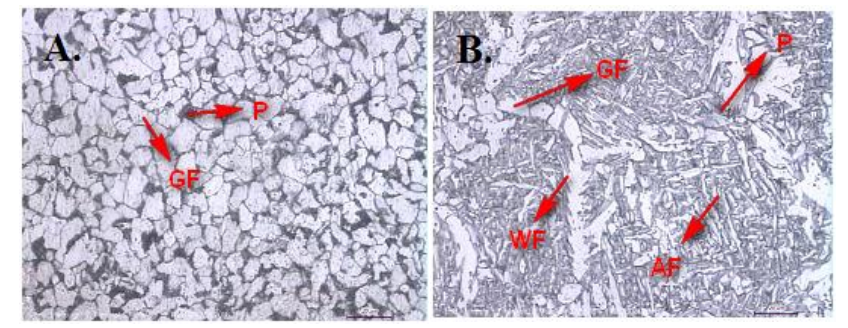

Gambar 7. Hasil pengujian metalografi pada daerah weld metal spesimen las yang mengalami kegagalan (A) dan spesimen las pembanding (B)

\section{Keterangan:}

$\mathrm{GF}=$ Grain boundary ferit

$\mathrm{WF}=$ Widmanstatten ferit

$\mathrm{AF}=$ Asikular ferit

$\mathrm{P} \quad=$ Perlit

Berdasarkan data yang diperoleh dari hasil pengujian metalografi, didapatkan persamaan pada daerah base metal maupun heat affected zone dengan fasa dan ukuran butir yang hampir sama. Namun, didapatkan perbedaan pada daerah weld metal spesimen las yang mengalami kegagalan dengan spesimen las pembanding serta spesimen las yang jauh dari lokasi kegagalan.

\section{E. Hasil Pengujian Visual}

Pengujian visual dilakukan pada spesimen las yang mengalami kegagalan untuk mengamati penyebab terjadinya kebocoran pada tube.

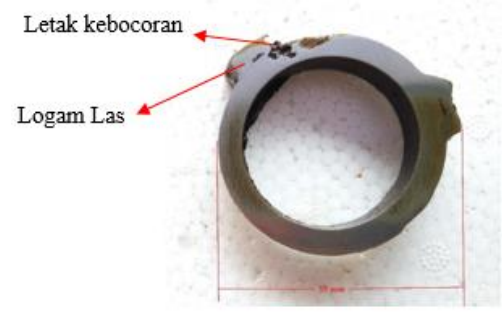

Gambar 8. Potongan tube yang mengalami kegagalan

Dari hasil pengamatan visual secara makro menggunakan kamera pada tube yang mengalami kegagalan pada gambar 8 , didapat gambar kerusakan yang terlihat. Kebocoran terjadi pada daerah las dan akibat dari kebocoran tersebut tube boiler di dekat daerah tersebut juga mengalami erosi karena adanya semburan gas.

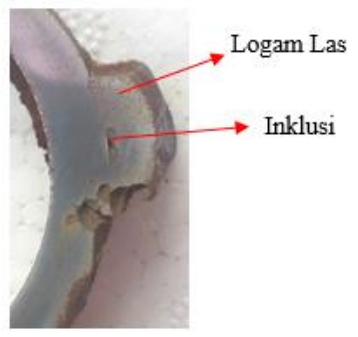

Gambar 9. Inklusi pada logam las
Gambar 9 menunjukkan adanya inklusi yang berada disambungan antara logam las dengan base metal.

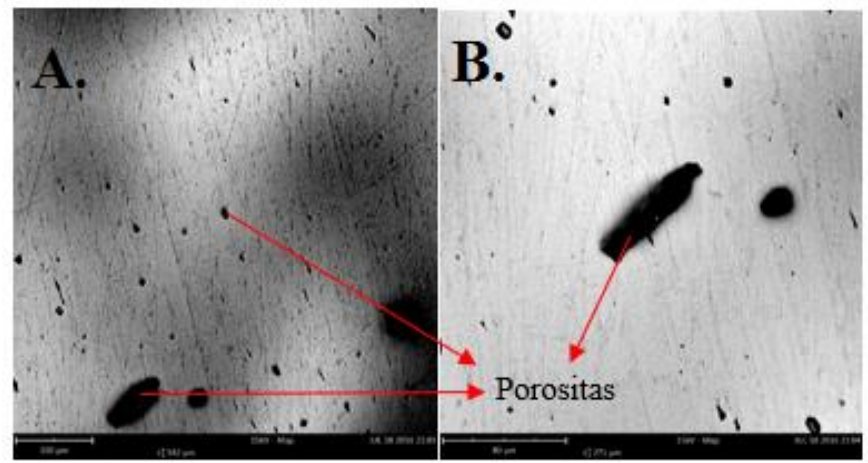

Gambar 10. Hasil Pengujian SEM dengan perbesaran sebesar 500x (A) dan perbesaran sebesar 1000x (B)

Gambar 10 merupakan hasil dari uji SEM dan menunjukkan adanya porositas di daerah weld metal pada spesimen las yang mengalami kegagalan.

\section{F. Hasil Pengujian Kekerasan}

Pengujian kekerasan dilakukan untuk mengetahui nilai kekerasan pada spesimen las yang mengalami kegagalan maupun spesimen las pembanding. Berikut merupakan hasil pengujian kekerasan:

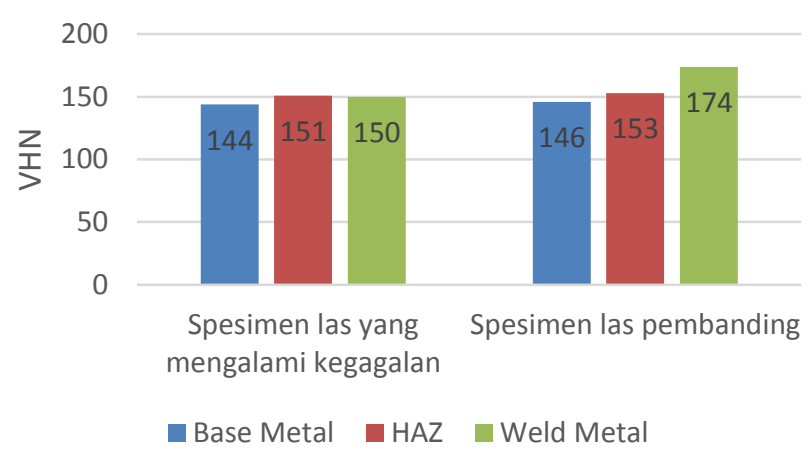

Gambar 11. Perbandingan distribusi nilai kekerasan rata - rata ketiga daerah (base metal, HAZ, dan weld metal) pada kedua spesimen

\section{G. Hasil Pengujian XRD}

Pengujian XRD dilakukan pada spesimen las yang mengalami kegagalan. Pengujian ini bertujuan untuk mengetahui adanya korosi pada spesimen tersebut. Berikut merupakan hasil dari pengujian XRD: 


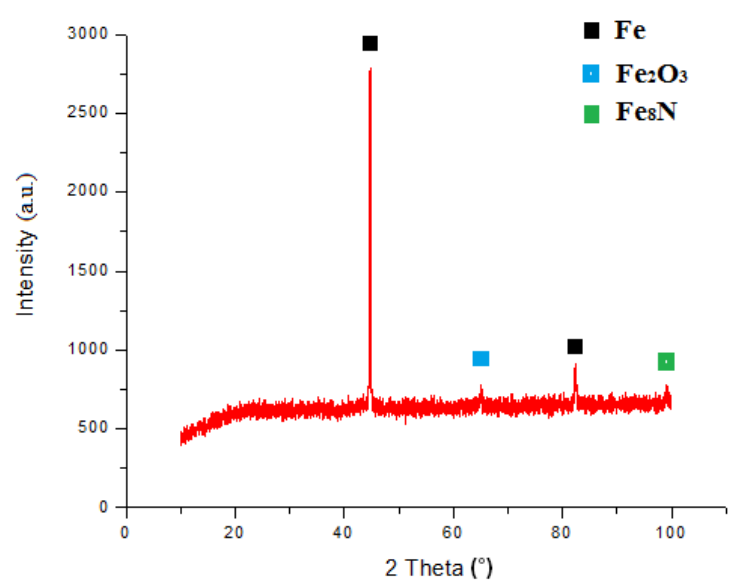

Gambar 12. Hasil pengujian XRD

Hasil pengujian XRD menunjukkan adanya unsur tunggal $\mathrm{Fe}$, senyawa $\mathrm{Fe}_{2} \mathrm{O}_{3}$ dan senyawa $\mathrm{Fe}_{8} \mathrm{~N}$.

\section{H. Pembahasan}

Penelitian ini diawali dengan pembuatan spesimen las pembanding dengan menggunakan welding procedure specification yang sama sebagai acuan. Pengujian pertama yang dilakukan adalah pengujian spektrometri. Pengujian ini dilakukan untuk mengetahui komposisi pada spesimen las yang mengalami kegagalan. Sesuai dengan tabel 1, hasil dari pengujian spektrometri menunjukkan kesesuaian dengan komposisi pada material AWS E7016 sebagai elektroda yaitu baja Karbon rendah dengan Mangan sebagai paduan utama

Pengujian selanjutnya adalah pengujian penetrant. Pengujian penetrant dilakukan di daerah las pada spesimen las pembanding untuk mengetahui apakah terjadi cacat permukaan atau tidak. Berdasarkan hasil yang didapat dari pengujian ini (gambar 2) spesimen las pemnbanding tidak ditemukan adanya cacat permukaan pada daerah las.

Pengujian selanjutnya adalah pengujian tarik. Pengujian tarik dilakukan pada spesimen las pembanding dengan tujuan untuk mengetahui apakah las pada spesimen pembanding telah terbuat dengan baik atau tidak. Pada gambar 4 ditunjukkan hasil dari pengujian tarik pada spesimen. Hasilnya adalah terjadi patahan pada daerah base metal. Dari pengujian penetrant dan pengujian tarik yang telah dilakukan dapat disimpulkan bahwa spesimen las pembanding telah dibuat dengan baik karena tidak ditemukan cacat permukaan pada daerah lasnya serta dari hasil pengujian tarik menunjukkan patah yang terjadi di bagian base metal.

Pengujian metalografi juga dilakukan pada penelitian ini. Pengujian ini dilakukan untuk mengamati fasa pada spesimen las yang mengalami kegagalan, spesimen pembanding, dan spesimen las yang jauh dari lokasi kebocoran. Pengamatan dilakukan pada tiga daerah yang berbeda pada masing - masing spesimen, yaitu pada base metal, heat affected zone, dan weld metal. Base metal pada kedua spesimen menunjukkan hasil yang sama, yaitu terdapatnya fasa grain boundary ferit dan perlit serta dengan ukuran butir yang hampir sama. Fasa tersebut sesuai dengan diagram $\mathrm{Fe}-\mathrm{Fe} 3 \mathrm{C}$, yaitu baja dengan wt\% karbon $0.15-0.27 \%$ pada temperatur dibawah $723{ }^{\circ} \mathrm{C}$ adalah pearlite dan ferrite [9]. Pada gambar 5 ditunjukkan hasil metalografi pada heat affected zone dari kedua spesimen. Kedua spesimen menunjukkan fasa yang sama yaitu grain boundary ferit, widmanstatten ferit, dan perlit serta dengan ukuran butir yang hampir sama. Karena adanya pengaruh panas pada saat pengelasan, bentuk butir pada daerah heat affected zone berbeda dengan bentuk butir dari base metal. Butir ferit yang didapat menunjukkan bentuk yang lebih kecil serta cenderung memanjang dank arena ada pengaruh panas juga menyebabkan munculnya widmanstatten ferit pada daerah ini. Daerah weld metal, sesuai dengan gambar 7 , pada spesimen las pembanding dan spesimen las yang jauh dari lokasi kebocoran menunjukkan hasil yang sama tetapi terdapat perbedaan dengan spesimen las yang mengalami kegagalan. Didapatkan fasa poligonal ferit dengan sedikit perlit pada spesimen las yang mengalami kegagalan serta pada spesimen las pembanding dan spesimen las yang jauh dari lokasi kebocoran menunjukkan fasa grain boundary, widmanstatten ferit, asikular ferit dan sedikit perlit. Berdasarkan hasil yang didapatkan dari pengujian metalografi, perbedaan yang signifikan hanya terdapat pada daerah weld metal sehingga dapat ditarik kesimpulan bahwa ada kesalahan pada daerah ini.

Pengujian selanjutnya adalah pengujian kekerasan. Pengujian ini dilakukan untuk mengetahui nilai kekerasan dari kedua spesimen dan juga berguna untuk mendapatkan nilai kekuatan pada daerah las dari kedua spesimen. Sesuai dengan kurva pada gambar 11, distribusi nilai kekerasan rata - rata yang didapat pada daerah base metal, heat affected zone, dan weld metal scara berturut - turut pada spesimen las yang mengalami kegagalan adalah $144 \mathrm{HV}, 151 \mathrm{HV}$, dan $150 \mathrm{HV}$. Sedangkan distribusi nilai kekerasan rata - rata yang didapat pada daerah base metal, heat affected zone, dan weld metal scara berturut - turut pada spesimen las pembanding adalah 146 HV, $153 \mathrm{HV}$, dan $174 \mathrm{HV}$. Dari kedua spesimen, nilai kekerasan pada heat affected zone lebih tinggi dibandingkan dengan nilai kekerasan pada base metal, hal ini dikarenakan adanya widmanstatten ferit yang lebih keras. Daerah weld metal merupakan daerah dengan nilai kekerasan yang paling tinggi karena adanya asikular ferit yang bersifat lebih keras. Berdasarkan data yang diperoleh, nilai kekerasan yang berbeda signifikan hanya pada daerah weld metal, yaitu $150 \mathrm{HV}$ pada spesimen las yang mengalami kegagalan dan $174 \mathrm{HV}$ pada spesimen las pembanding. Hal ini juga didukung dari hasil pengujian metalografi pada daerah weld metal dengan didapatkannya fasa asikular ferit pada spesimen pembanding karena sifatnya yang lebih keras dan kuat. Jika dikonversi menjadi nilai kekuatan, pada spesimen las yang mengalami kegagalan diperoleh nilai kekuatan sebesar $479 \mathrm{MPa}$, sedangkan pada spesimen las pembanding diperoleh nilai kekuatan sebesar $550 \mathrm{MPa}$. Standar AWS E7016 memiliki nilai kekuatan minimal sebesar $490 \mathrm{MPa}$ sehingga spesimen las yang gagal tidak memenuhi standar minimal kekuatannya dan spesimen las pembanding memiliki nilai kekuatan yang lebih dari standar.

Pengamatan visual juga dilakukan pada spesimen las yang mengalami kegagalan. Pada gambar 9 menunjukkan adanya 
inklusi pada bagian antara logam las dengan base metal serta pada gambar 10 menunjukkan adanya porositas yang terbentuk pada logam las. Inklusi dan porositas terbentuk karena adanya kesalahan dalam proses las. Inklusi merupakan pengotor yang masuk kedalam weld pool dan porositas merupakan adanya rongga kosong pada weld pool karena adanya udara yang terperangkap. Baik inklusi maupun porositas, keduanya dapat menurunkan kualitas dari hasil las.

Pengujian yang terakhir adalah pengujian XRD. Pengujian ini dilakukan untuk mengetahui adanya senyawa korosi pada spesimen las yang mengalami kegagalan. Gambar 12 menunjukkan hasil pengujian XRD pada spesimen tersebut dan didapatkan adanya unsur tunggal $\mathrm{Fe}$ dan senyawa $\mathrm{Fe}_{2} \mathrm{O}_{3}$ serta $\mathrm{Fe}_{8} \mathrm{~N}$. Dengan adanya unsur tunggal $\mathrm{Fe}$ menunjukkan adanya korosi. Produk korosi yang terbentuk adalah $\mathrm{Fe}_{2} \mathrm{O}_{3}$ dan $\mathrm{Fe}_{8} \mathrm{~N}$. $\mathrm{Fe}_{2} \mathrm{O}_{3}$ terbentuk karena $\mathrm{Fe}$ pada daerah las bereaksi dengan $\mathrm{H}_{2} \mathrm{O}(\mathrm{g})$ dari hasil pemanasan feedwater. $\mathrm{Fe}_{8} \mathrm{~N}$ terbentuk akibat Fe pada daerah las bereaksi dengan $\mathrm{NO}_{\mathrm{x}}$ dari emisi pembakaran batubara [10]. Dengan terbentuknya dua senyawa korosi ini mengakibatkan berkurangnya kualitas pada lasan tersebut.

Berdasarkan pengujian - pengujian yang telah dilakukan, didapatkan hasil yang berbeda pada weld metal spesimen las yang mengalami kegagalan jika dibanding dengan spesimen pembanding. Pada hasil metalografi menunjukkan kesamaan pada spesimen las pembanding dan spesimen las yang jauh dari lokasi kebocoran tetapi terdapat perbedaan dengan spesimen las yang mengalami kegagalan, yaitu didapatkannya butir yang lebih besar pada spesimen las yang mengalami kegagalan. Hal ini dipengaruhi oleh heat input pada proses pengelasan. Heat input yang kurang menyebabkan ukuran butir hasil las menjadi lebih besar sehingga memiliki kekuatan yang lebih rendah. Sehingga dapat disimpulkan bahwa terjadi kesalahan proses pengelasan pada spesimen las yang mengalami kegagalan. Spesimen las pembanding yang dibuat juga dapat direkomendasikan untuk proses pengelasan yang benar.

\section{KESIMPULAN}

Berdasarkan hasil pengujian yang telah dilakukan maka didapatkan kesimpulan sebagai berikut:

1) Faktor utama penyebab kegagalan pada hanger tube outlet section secondary superheater adalah karena adanya kesalahan saat proses pengelasan.

2) Mekanisme terjadinya kebocoran ini yaitu dipicu dengan tidak sesuainya spesifikasi las yang terbentuk dengan standar pengelasan sehingga terjadi kebocoran. Dari hasil pengujian metalografi, pada spesimen las yang mengalami kegagalan didapatkan fasa grain boundary ferit dan perlit, sedangkan pada spesimen las pembanding didapatkan fasa grain boundary ferit, widmanstatten ferit, asikular ferit dan dengan sedikit perlit. Didapatkan juga senyawa korosi, inklusi, dan porositas pada daerah las yang menyebabkan kualitas las menjadi tidak maksimal.

3) Spesimen las pembanding yang dibuat dapat dijadikan acuan dalam proses pengelasan yang seharusnya.

\section{DAFTAR PUSTAKA}

[1] __ 1998. Steam Generation. Charlotte: The Babcock \& Wilcox Company.

[2] McIntyre, Keith B. 2002. A Review of The Common Causes of Boiler Failure in The Sugar Industry. Alstom Power: 355-364.

[3] Woodruff, E.B., H.B. Lammers, dan T.F. Lammers. 2004. Steam Plant Operation 8th Edition. New York: McGraw-Hill.

[4] __ 2002. ASTM A 210/A 210 M Standard Specification for Seamless Medium-Carbon Steel Boiler and Super Heater Tubes. West Conshohocken: ASTM International.

[5] _ _ 2012. Kobelco Welding Consumables. Indonesia: PT Intan Pertiwi Industri

[6] _ 2002. ASTM E8 Standard Guide for Preparation of Tensile Testing. West Conshohocken: ASTM International

[7] __ 2002. ASTM E3 Standard Guide for Preparation of Metallographic Specimens. West Conshohocken: ASTM International

[8] _ 2002. ASTM E92 Standard Guide for Preparation of Hardness Testing. West Conshohocken: ASTM International

[9] Avner, Sidney H. 1974. Introduction to Physical Metallurgy. Singapore: McGraw-Hill Book Co.

[10] Woodruf, E.B., H.B. Lammers, dan T.F. Lammers. 2004. Steam Plant Operation $8^{\text {th }}$ Edition. New York: McGraw-Hill 